Participatory Educational Research (PER)

Special Issue 2016-II, pp., 71-79; 01 February 2016

Available online at http://www.partedres.com

ISSN: 2148-6123

http://dx.doi.org/10.17275/per.16.spi.2.8

\title{
Examination and Evaluation of Websites of Science Centres in Turkey
}

\author{
Aykut Emre BOZDOĞAN* \\ Gaziosmanpaşa University, Faculty of Education, Tokat, Turkey
}

Kerem BOZDOĞAN

Necmettin Erbakan University, The Institute of Educational Sciences, Konya, Turkey

\begin{abstract}
Science centres which have a considerable importance and functions in developed countries are intended to be popularized in Turkey. At this point considering the fact that the first contact between science centres and visitors is usually provided with websites, it is quite important that the content of these websites should be designed and developed to meet the needs of the visitors. From this point of view, the aim of this study is to examine the websites of the science centres in Turkey and to reveal at what level they meet the needs of the visitors. The research study was carried out via descriptive survey method and between September 14 and September 18, 2015 the key word "science centre" was searched on Google. Out of the science centres found, twelve science centres were included in the study. During the process of analysis of the documents obtained, two researchers examined every single data on the website separately and then they combined and tabulated them. Within this context, four main titles were obtained: a) information and news b) activities and the documents, c) Visuals, and d) Contact, Appointment, and Booking. At the end of the study, it was determined that under some circumstances the websites of the science centres were useful, where as they were inadequate under some conditions.
\end{abstract}

Keywords: Science Centre, Website, Informal Learning, Science Education

Not: P.S: This study was supported by Giresun University Scientific Research Projects Commission (BAP) (Project Number: EĞT-BAP-A-200515-56)

\section{INTRODUCTION}

Science centres contain science, technology, and education in itself and also they are one of the rare institutions which make contributions to science education and professional training by building a bridge between science-education and technology-education (Bozdoğan, 2007). The recent research studies carried out have revealed that science centres have functions to complement the education in schools (Yu, 1999). It is particularly stated that science centres are effective in developing students' science process skills, learning 
variety of science subjects by discovery, increasing students' academic achievement and attitudes towards science, raising their scientific curiosity, and facilitating learning (Chin, 2004; Cox-Petersen, 1999; Griffin, 2004; Guisasola, Morentin and Zuza, 2005).

Science centres which have considerable functions and importance about teaching of science in developed countries are intended to be popularized in our country. Within this scope, the Scientific and Technological Research Council of Turkey (TUBITAK) took a decision to set up science centres in big cities at the first stage and then in 81 cities to popularize science culture in line with the decision of the Supreme Council for Science and Technology (BTYK) and carried it into action.

At this point, an important factor arises. Considering the fact that the first contact between science centres and visitors is usually provided with websites, it is quite important that the content of these websites should be designed and developed to meet the needs of the visitors. When the prominent and institutionalized science centres in the world like German Museum (The Deutsches Museum ) in Germany, London Science Museum in England, The Exploratorium in the USA, and The Ontario Science Centre in Canada are examined in literature, it is found that they present many information, visuals, and documents which will address the needs of the visitors on their websites. From this point of view, the aim of this study is to reveal at what level the websites of existing science centres in Turkey meet the needs of the visitors after analysing the websites and also to offer a perspective about the content of the websites belonging to the science centres which will be founded in the future.

\section{METHOD}

\section{The Research Method}

Cross-sectional survey, one of the descriptive research methods, was used in the research. This method was utilised in the research study because science centres in Turkey were considered to be described by determining at what levels they meet the needs of the visitors, particularly students and teachers. The websites which were examined were identified considering the points mentioned below.

\section{Limitations}

(1) "Google", a web search engine, was used to identify the websites.

(2) The key word "Science centre" was searched.

(3) The websites included in the research were examined between September 14 and 18, 2015. 4. The information found in the websites were utilised in the research on these dates. As a result of the analysis, twelve science centres were considered appropriate to be included in the research study.

The websites included in the study and their access addresses were presented in Table 1.

Table 1. The websites of the science centres included in the research and their access addresses

\begin{tabular}{ll}
\hline Science Centre & Access Adress \\
\hline 1. Konya Science Centre & http://www.kbm.org.tr \\
2. İTÜ Science Centre & http://www.bilimmerkezi.itu.edu.tr/ \\
3. Kocaeli Science Centre & http://www.kocaelibilimmerkezi.com/ \\
\hline
\end{tabular}




$\begin{array}{ll}\text { 4. METU Society and Science Res. and App. Cen. } & \text { https:/tbm.metu.edu.tr/ } \\ \text { 5. Bursa Science and Technology Centre } & \text { http://www.bursabilimmerkezi.org/ } \\ \text { 6. Gaziantep Planetarium and Science Centre } & \text { http://gezegenevi27.com.tr/ } \\ \text { 7. Feza Gürsey Science Centre } & \text { http://www.fezagurseybilimmerkezi.com/ } \\ \text { 8. Ankara Children's Museum and Science Centre } & \text { http://ankaracocukmuzesi.com/ } \\ \text { 9. Sancaktepe Science and Experiment Centre } & \text { http://www.sabidem.org/ } \\ \text { 10. Eskişehir Science and Experiment Centre } & \text { http://www.eskisehirbilimdeneymerkezi.com/ } \\ \text { 11. Gölbaş1 Munacipality Science Centre } & \text { http://golbasibilimmerkezi.com/ } \\ \text { 12. Bayrampaşa Munacipality Science Centre } & \text { http://bayrampasabilimmerkezi.com/ }\end{array}$

\section{Data Collection Tools and Data Analysis}

Content evaluation forms for science centres designed and developed by the researchers were used to gather data. First of all, the science centres both in Turkey and in the world were examined and the existing content or the required content was listed. Then, the titles in this list were combined and four main titles were obtained. After two different experts reviewed them, the data collection tool was finalized. These four main titles in the data collection tool and their subtitles were presented as follows:

a) Information and News: The latest news about the scientific activities and developments both in the science centre and in the world are given and thus the contributions they make to the visitors to gain information about the scientific advancements have been analysed.

b) Activities and Documents: In this section, the activities and the documents involved in the science centres were examined. In addition, whether the science centres had education programs were analysed under this title.

c) Visuals: In this section, whether photographs, panoramic photo and videos related to the content of the science centre existed or not was examined.

d) Contact, Appointment and Booking: Under this title, how to get in contact with the science centre, to make the necessary appointments, and to make reservations were explored. Considering the general purpose of the study, frequency and percentage values, one of the descriptive statistics, were given for the required statistical analysis of the data and they were evaluated.

\section{FINDINGS}

The websites of science centres giving information and news were presented in Table 2 .

Table 2. Frequency and percentages distribution of websites of science centres giving information and news

\begin{tabular}{|c|c|c|c|c|c|c|c|c|c|c|c|c|c|c|}
\hline $\begin{array}{l}\text { Main Title } \\
\text { Information and News }\end{array}$ & \multicolumn{14}{|c|}{ Science Centres } \\
\hline Content & $\begin{array}{l}U \\
\dot{\infty} \\
\tilde{\sigma} \\
\overrightarrow{0} \\
\underline{0}\end{array}$ & $\begin{array}{l}\dot{U} \\
\dot{\sim} \\
:\end{array}$ & 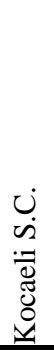 & $\stackrel{?}{\stackrel{2}{\longrightarrow}}$ & 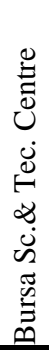 & 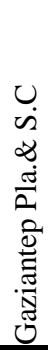 & 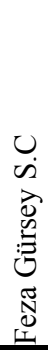 & 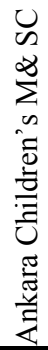 & 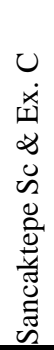 & 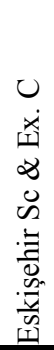 & 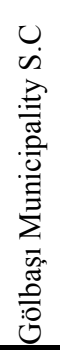 & 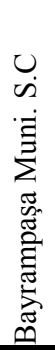 & f & $\%$ \\
\hline 1.About us/Who we are & ? & 0 & 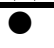 & $\overline{0}$ & $\overline{0}$ & 0 & 0 & 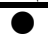 & 0 & $\overline{0}$ & 0 & $\overline{0}$ & 9 & $\overline{75.0}$ \\
\hline 2. News from science centre & 0 & @ & 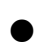 & 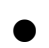 & ○ & 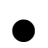 & 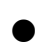 & $\mathbf{0}$ & 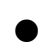 & 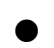 & $\bullet$ & ○ & 9 & 75.0 \\
\hline 3. Media Coverage/Press releases & 0 & 0 & O & 0 & 0 & 0 & 0 & 0 & ○ & 0 & 0 & $\mathbf{0}$ & 4 & 33.3 \\
\hline
\end{tabular}




\begin{tabular}{lllllllllllllll}
\hline 4. Scientific news & 0 & $@$ & 0 & 0 & 0 & 0 & $@$ & 0 & 0 & 0 & 0 & 0 & $\mathbf{3}$ & $\mathbf{2 5 . 0}$ \\
5. Writers & 0 & 0 & 0 & 0 & 0 & 0 & 0 & 0 & 0 & 0 & 0 & 0 & $\mathbf{1}$ & $\mathbf{0 8 . 3}$ \\
\hline
\end{tabular}

-Adequate information was given and explanations were made. O-Partial information was given. It is not adequate and updated. O- The link does not work or no information was found. @- There is no information on the WEB site but information was given on social networking sites (Facebook, Twitter, Instagram, Youtube and etc.,).

When Table 2 was examined, it was revealed that out of the 12 websites included in the research, nine of them introduced the science centres and they also included current news about the science centres and made adequate explanations. Moreover, four of them consisted of the latest press releases about the science centre on their websites; three of them had current articles with scientific content, and one of them included current articles of the writers. The websites of science centres giving information about the activities carried out and the documents offered were presented in Table 3.

Table 3. Frequency and percentages distribution of the websites of science centres giving information the activities carried out and the documents offered

\begin{tabular}{|c|c|c|c|c|c|c|c|c|c|c|c|c|c|c|}
\hline Main Title & Sci & ice & entre & & & & & & & & & & & \\
\hline Content & $\begin{array}{l}u \\
\dot{v} \\
\widetilde{\sigma} \\
\stackrel{\Xi}{0} \\
\underline{0}\end{array}$ & $\begin{array}{l}\dot{u} \\
\dot{S} \\
: \\
:\end{array}$ & 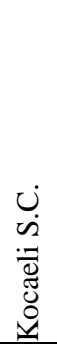 & $\stackrel{?}{\stackrel{2}{2}}$ & 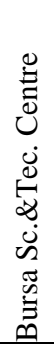 & 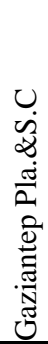 & 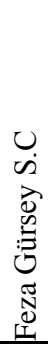 & 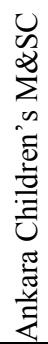 & 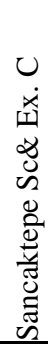 & 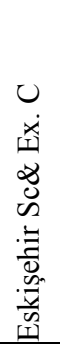 & 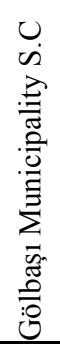 & 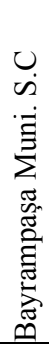 & f & $\%$ \\
\hline $\begin{array}{l}\text { 1. Summer schools, camps, festivals, } \\
\text { workshops } \\
\text { 2. Activities/Exhibitions }\end{array}$ & ○ & $\overline{0}$ & 0 & $\overline{0}$ & 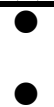 & 0 & $@$ & 0 & 0 & 0 & 0 & $\overline{0}$ & $\overline{11}$ & $\overline{91.6}$ \\
\hline $\begin{array}{l}\text { 3. Events calendar } \\
\text { 4. e-bulletin } \\
\text { 5. Education program related to the } \\
\text { courses and teacher's guide } \\
\text { 6. Library }\end{array}$ & $\stackrel{0}{0}$ & $\begin{array}{l}0 \\
0 \\
0\end{array}$ & $\begin{array}{l}0 \\
0 \\
0\end{array}$ & $\begin{array}{l}0 \\
0 \\
0\end{array}$ & $?$ & $\begin{array}{l}0 \\
0 \\
0\end{array}$ & $\begin{array}{l}0 \\
0 \\
0\end{array}$ & $\stackrel{0}{0}$ & $\begin{array}{l}0 \\
0 \\
0\end{array}$ & $\stackrel{?}{\bullet}$ & $\stackrel{0}{\bullet}$ & $\begin{array}{l}0 \\
0 \\
0\end{array}$ & $\begin{array}{l}6 \\
6 \\
4\end{array}$ & $\begin{array}{l}50.0 \\
50.0 \\
33.3\end{array}$ \\
\hline
\end{tabular}

-Adequate information was given and explanations were made. O-Partial information was given. It is not adequate and updated. O- The link does not work or no information was found. @- There is no information on the WEB site but information was given on social networking sites (Facebook, Twitter, Instagram, Youtube and etc.).

When Table 3 was examined, it was found that nearly all of the websites of the science centres offered enough information about the camps, festivals, workshops, and summer schools they organized and nine of them presented enough information about the content of the activities performed or included in the science centres. There are only four science centres which had curriculum connections with various courses and teacher's guide.

The visuals presented by the science centres were examined and given in Table 4. 
Table 4. Frequency and percentages distribution of the websites of science centres' visuals related to their contents

\begin{tabular}{|c|c|c|c|c|c|c|c|c|c|c|c|c|c|c|}
\hline Main Title & Scie & ace ( & entre & & & & & & & & & & & \\
\hline Content & 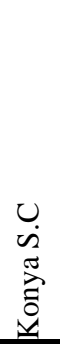 & $\begin{array}{l}\dot{U} \\
\dot{\omega} \\
:\end{array}$ & 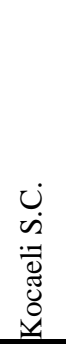 & $\stackrel{?}{\stackrel{?}{\nu}}$ & 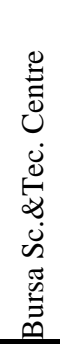 & 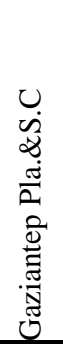 & 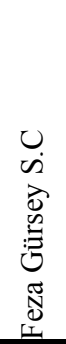 & 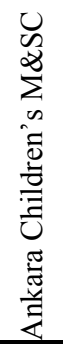 & 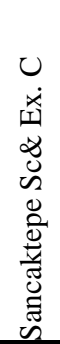 & 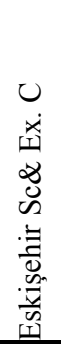 & 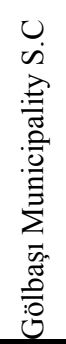 & 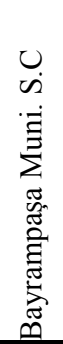 & f & $\%$ \\
\hline 1. Gallery and Photos & 0 & 0 & 0 & 0 & 0 & 0 & 0 & 0 & 0 & 0 & 0 & 0 & 10 & 83.3 \\
\hline 2. Videos & 0 & 0 & @ & $@$ & $\bullet$ & $\mathbf{0}$ & @ & 0 & 0 & 0 & 0 & $\bullet$ & 4 & 33.3 \\
\hline 3. Panoramic Photos & 0 & 0 & 0 & 0 & 0 & 0 & 0 & O & 0 & 0 & 0 & 0 & 1 & 8.3 \\
\hline
\end{tabular}

When Table 4 was examined, it was determined that ten science centres contained photos related to their content and four science centres presented videos. It was revealed that only one science centre included panoramic photographs related to their content.

Whether websites of science centres offered contact, appointment, and booking were examined and they were presented in Table 5.

Table 5. Frequency and percentages distribution of the websites of science centres offering contact, appointment, and booking

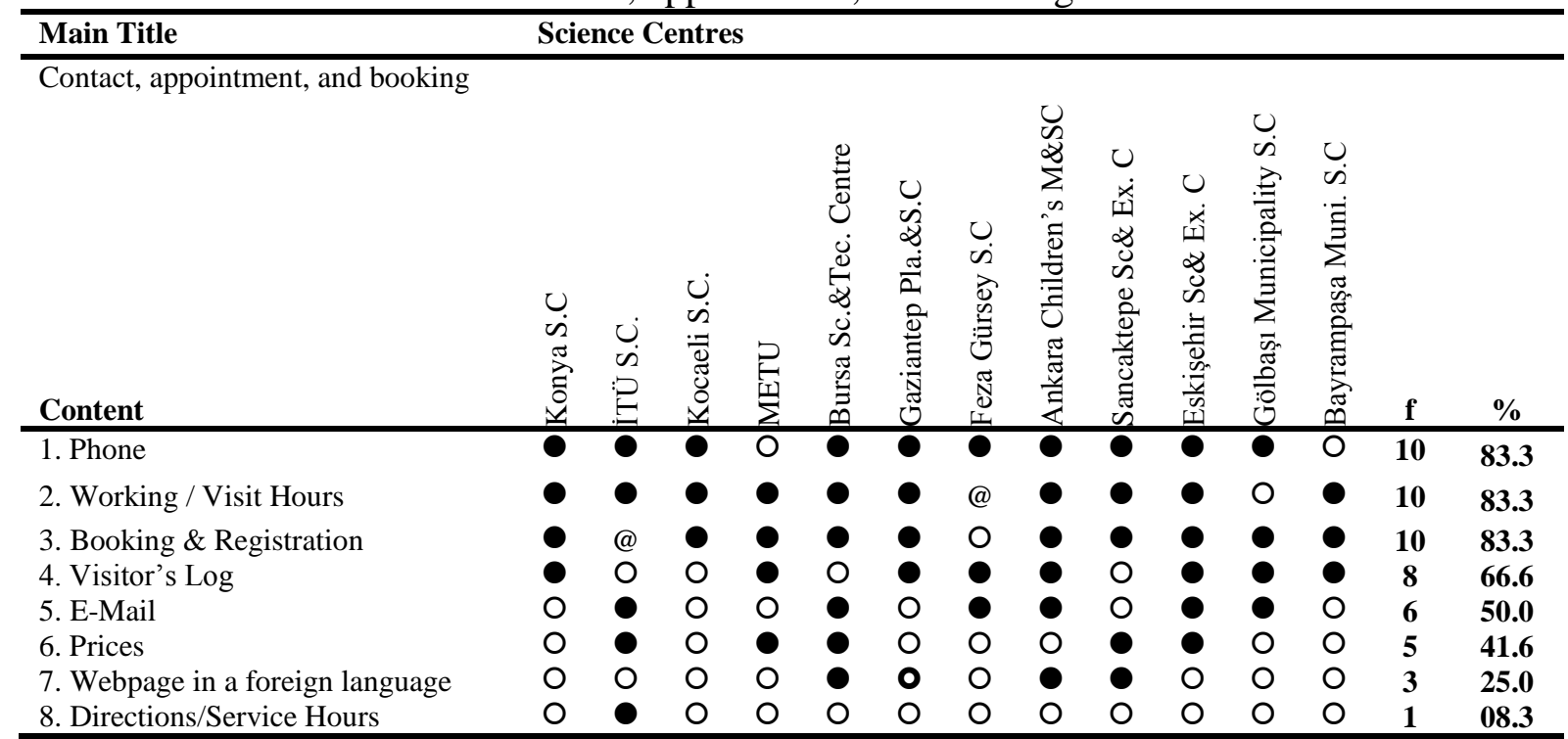

-Adequate information was given and explanations were made. $\mathbf{O}$-Partial information was given. It is not adequate and updated. O- The link does not work or no information was found. @- There is no information on the WEB site but information was given on social networking sites (Facebook, Twitter, Instagram, Youtube and etc.,).

When Table 5 was examined, it was revealed that ten science centres had phone numbers and visit hours for contact on their websites and they also included information regarding online booking and registration on their websites. It was also found that only three of the science centres' websites were in English. During the study conducted, it was found that science centres used their social media accounts to give information about their contents and which 
social media accounts they used were examined and they were presented in Table 5.

Table 6. Social media accounts of science centres

\begin{tabular}{|c|c|c|c|c|c|c|c|c|c|c|c|c|c|c|}
\hline \multirow{2}{*}{$\begin{array}{l}\text { Main Title } \\
\text { Social Media }\end{array}$} & \multicolumn{14}{|c|}{ Science Centres } \\
\hline & 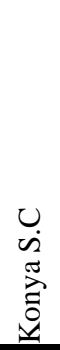 & $\begin{array}{l}\dot{U} \\
\dot{\Omega} \\
:\end{array}$ & 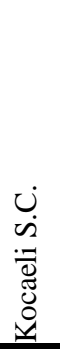 & $\stackrel{?}{\stackrel{2}{2}}$ & 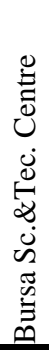 & 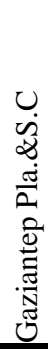 & 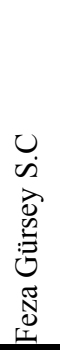 & 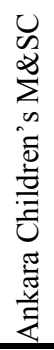 & 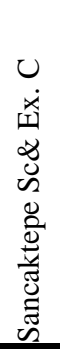 & 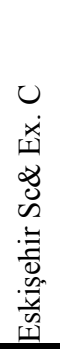 & 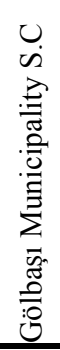 & 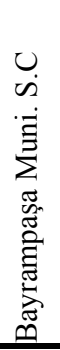 & $\mathbf{f}$ & $\%$ \\
\hline Facebook & 0 & 0 & 0 & 0 & 0 & 0 & 0 & 0 & 0 & 0 & 0 & 0 & 9 & 75.0 \\
\hline Twitter & o & 0 & 0 & 0 & ○ & $\bullet$ & 0 & 0 & 0 & 0 & 0 & o & 8 & 66.6 \\
\hline $\begin{array}{l}\text { Youtube } \\
\text { Instagram }\end{array}$ & ? & $\stackrel{0}{0}$ & $?$ & $\stackrel{0}{0}$ & ○ & $\begin{array}{l}0 \\
0\end{array}$ & $\begin{array}{l}0 \\
0\end{array}$ & $\begin{array}{l}0 \\
0\end{array}$ & $?$ & $\begin{array}{l}0 \\
0\end{array}$ & $\begin{array}{l}\mathbf{0} \\
0\end{array}$ & $\begin{array}{l}0 \\
0\end{array}$ & $\begin{array}{l}6 \\
2\end{array}$ & $\begin{array}{l}50.0 \\
16.6\end{array}$ \\
\hline
\end{tabular}

-Actively used social media accounts. O-The link does not work. O-No accounts

When Table 6 was examined, it was revealed that apart from their websites, science centres actively gave information about their contents via their Facebook ( 9 science centres), Twitter (8 science centres) and Youtube (6 science centres) accounts.

\section{RESULTS, DISCUSSION AND RECOMMENDATIONS}

As a result of the study conducted, it was found that three quarters of the twelve science centres gave information with the intention of publicity on their web pages and they included current news related to the science centres. These results show that the science centres can introduce themselves to their visitors efficiently. However, it was revealed that one-third of the science centres which were examined included news coverage about their activities in media and three quarters of them published current scientific news on their websites. Within this context, science centres act like a bridge between science and public and their mission is to popularise science but their failure to present current scientific developments which are attention-grabbing on their websites can be regarded as a weakness. Another result found in the study is that the science centres included information about the "camps, festivals, workshops, and summer schools organized" on almost all the websites. Moreover, it was determined that three -quarters of them had enough information about the contents of the activities which existed and done in the science centres. These results exhibit that the websites of science centres which were examined contained enough data concerning the activities done and events organized. However, half of the websites of the science centres do not have events calendar about the activities performed and they do not publish e-bulletin. This result demonstrates that the websites are inadequate regarding meeting needs of the visitors because it is important that visitors should know which activity to do before planning their visits.

The most important result of this study is that only one-third of the websites of science centres presented content particularly to the teachers which form a basis for organizing curriculumbased field trips because if teachers know which exhibitions/activities to visit considering the courses/learning outcomes, it will facilitate teachers' work and it will also help to have a more 
meaningful trip. At this point, the studies carried out reveal that teachers may not be aware of the purposes of the trips they organized (Cox-Petersen et. al, 2003; Griffin, 1994, 2004; Kisiel, 2003; Price and Hein, 1991) and they have difficulties in establishing a relationship between the trips and course syllabus (Griffin and Symington, 1997; Kisiel, 2007; RameyGassert et. al, 1994). It is considerably important that science centres should eliminate this weakness and they should present their activity plans which are related to the curriculum on their websites. Thus, it will be of great benefit to review the Science curriculum for Grades 38 which was updated in 2013. According to the Science curriculum which was updated in 2013 for Grades 3-8, “...Because students should learn the knowledge in the field of science meaningfully and permanently, in-class and out -of class settings should be designed based on inquiry-based learning strategy. In this regard, informal learning environments are utilised." and this statement refers to out-of-school settings (MEB, 2013). This condition clearly reveals that a bridge must be established between Science course and science centres because the attitudes towards science and the relationship between the science curriculum which comprises the basis for scientific thinking system and scientific knowledge and science centres will make important contributions to raising younger generation who are science literate, and like, understand and use/produce science.

The examination results under the visuals title demonstrated that nearly all of the websites presented photos about their contents and thus informed their visitors. Moreover, only onethird of the science centres' websites had videos related to the activities done and only one of them included panoramic photographs. At this point, presenting only photos about the content of the exhibitions seems to be moderately adequate. However, it is considerably important that the videos of the exhibitions and the activities performed should be shared on the websites for those who could not have an opportunity to visit a science centre due to some reasons (financial problems, security, time, distance, being unable to get a permission from the families, and so on), and particularly for students to inform them and to increase their interest in science because today a lot of museums and science centres provide opportunities to their visitors to visit them in a virtual environment via image transfer methods and access technology (Güleç and Alkış, 2003; Tepecik, 2008). In addition, the studies reveal that virtual visits/trips make contributions to students' cognitive and affective learning (Demirboğa, 2010; Durmuş, 2012; Stinson, 2001; Uslu, 2008; Yıldırım and Tahiroğlu, 2012) and they promote the effectiveness of the real trips which will be organized (West, 1998).

It was found in the study that nearly all of the science centres had their phone numbers and emails on their websites. Furthermore, nearly all of them included working/ visit hours on their websites and they had information intended for the online booking/ registration. When these findings were evaluated, they were enough to meet the needs of the visitors. On the other hand, the science centres did not have enough information regarding the admission fee and providing services for the schools which visit them on their websites. Within this context, it is quite important that this information should be given on the websites to meet the needs of the schools that will visit the science centres. It was found in the study that apart from giving information about their content on their websites, the science centres provided this information about their content actively via their social media accounts. It was revealed that all science centres had a Facebook page, but the links given by three of them did not work. In addition, ten science centres had a Twitter account and the link belonging to two of them did not work. It is important that the links that do not work on the websites must be detected and these problems must be solved regarding meeting the needs of the visitors. Another finding in the study is that only one-fourth of the science centres' websites were in a foreign language (English). When it is considered that institutionalized science centres in the world host 
thousands of tourists each year, it is without doubt that science centres having websites in English will make positive contributions in terms of increasing visitor numbers and providing added value to our country.

In conclusion, it is known that regarding the decision of the Supreme Council for Science and Technology (BTYK), TUBITAK has taken a decision to establish science centres in 81 cities, primarily beginning with the big cities, to popularize science culture. Designing the websites of these science centres which are particularly planned to be founded by making a lot of investment with a professional team considering the examples in the world and providing contents which can meet all the needs of the visitors are as important as establishing science centres.

\section{REFERENCES}

Bozdoğan, A. E. (2007). Role and Importance Of Science And Technology Museum in Education. Unpublished doctoral dissertation, Gazi University, Enstitude of Educational Science. Ankara, Turkey. (Unpublished Doktoral Dissertation).

Chin, C. (2004). Museum experience - A resource for science teacher education. International Journal of Science and Mathematics Education, 2, 63-90.

Cox-Petersen A. M. (1999). Dive into research at the Aquarium. Science Activities. 36 (3), 34-36.

Cox-Petersen, A. M., Marsh, D. D., Kisiel, J., \& Melber, L. M. (2003). Investigation of guided tours, student learning and science reform. Reccomendations at a museum of natural history. Journal of Research in Science Teaching, 40, 200-218.

Demirboğa, E. (2010). Sanal Müze Ziyaretlerinin Öğrencilerin Bilişsel ve Duyuşsal Kazanımları Üzerindeki Etkileri. Gazi Üniversitesi, Eğitim Bilimleri Enstitüsü, Ankara. (Yayınlanmamış Yüksek Lisans Tezi).

Durmuş, A. (2012). Sanal Bilim ve Teknoloji Müzesinde Eğitsel Ara yüz Ajanı Kullanımının Öğrencilerin İlgi Ve Başarılarına Etkisi. Gazi Üniversitesi Eğitim Bilimleri Enstitüsü, Ankara. (Yayınlanmamış Doktora Tezi).

Griffin, J. (1994). Learning to learn in informal science settings. Research in Science Education, 24, 121-128.

Griffin, J. (2004). Research on students and museums: Looking more closely at the students in school groups. Science Education. 88 (Supp.-1), 59-70.

Griffin, J., \& Symington, D. (1997). Moving from task-oriented to learning-oriented strategies on school excursions to museums. Science Education, 81 (6), 763-779.

Guisasola, J; Morentin, M. and Zuza, K. (2005) School visits to science museums and learning sciences: A complex relationship. Physics Education. 40 (6), 544-549.

Güleç, S. \& Alkış, S. (2003). Sosyal Bilgiler öğretiminde müze gezilerinin iletişimsel boyutu. Uludağ Üniversitesi Ĕgitim Fakültesi Dergisi, 17(1), 63-78.

Kisiel, J. (2003). Teachers, museums, and worksheets: A closer look at learning experience. Journal of Science Teacher Education, 14, 3-21.

Kisiel, J. F. (2007). Examining teacher choices for science museum worksheets. Journal of Science Teacher Education, 18 (1), 29-43. 
MEB. (2013). 3-8. Sinıflar Fen Bilimleri dersi ögretim program. Talim ve Terbiye Kurulu Başkanlığı, Ankara.

Price, S., \& Hein, G. E. (1991). More than a field trip: Science programs for elementary school groups at museums. International Journal of Science Education, 13, 404-519.

Ramey-Gassert, L., Walberg III, H. J., \& Walberg, H. J. (1994). Reexamining connections: Museums as science learning environments. Science Education, 78, 345- 363.

Stinson, S. T. (2001) The Effect of Web-Based Museum Tour on The Social Studies Achievement Of Fifth Grade Student. University of Houston College of Education, Houston. (Unpublished Ph.D Thesis).

Tepecik, A. (2008). Sanat eğitimi ve sanal müze. Geçmişten Geleceğe Türkiye'de Müzecilik Sempozyum Bildiriler Kitabı, Ankara:Vekam Yayınları. 233- 240.

Uslu, Ö. (2008). İlköğretim İkinci Kademesinde Görsel Sanatlar Derslerinde Müze İle Eğitimin Etkileşimli (İnteraktif) Ortamda Gerçekleştirilmesi. Gazi Üniversitesi Eğitim Bilimleri Enstitüsü, Ankara (Yayınlanmamış Doktora Tezi).

West, S. E (1998) Art Museum Web Sites As Resources For Educators And Students: Development, Utilization And Evaluation. Thesis, The Florida State University, Art Education, Florida. (Unpublished Ph.D Thesis).

Y1ldırım, T \& Tahiroğlu, M. (2012). The effects of virtual museum visits on elementary students' attitudes towards social studies courses. Electronic Journal of Social Sciences, 11 (39), 104-114.

Yu, J.C. (1999). The National Science and Technology Museum of Taiwan. Technology and Culture. 40 (1), 107-113. 